\title{
Evaluation of Knowledge Levels of Individuals In Tokat City About Dental Implant Treatments: A Survey Study
}

\section{Tokat Şehrindeki Bireylerin Dental İmplant Tedavileri Hakkındaki Bilgi Düzeylerinin Değerlendirilmesi: Anket Çalışması}

\author{
¿Kaan Yerliyurt', Afra Eda Karadayı Yüzükcü1, @Yunus Balel², Osman Demir³ \\ 'Tokat Gaziosmanpaşa University Faculty of Dentistry Department of Prosthodontics, Tokat, Turkey \\ ${ }^{2}$ Tokat Gaziosmanpaşa University Faculty of Dentistry Department of Oral and Maxillofacial Surgery, Tokat, Turkey \\ ${ }^{3}$ Tokat Gaziosmanpaşa University Faculty of Medicine Department of Biostatistics, Tokat, Turkey
}

\begin{abstract}
Aim: Dental implant treatment is considered the gold standard today for the elimination of tooth loss. In this study; it was aimed to evaluate the knowledge levels of patients about dental implant treatments which ones referred to the Tokat Gaziosmanpaşa University Faculty of Dentistry, Clinic of Prosthetic Dentistry.

Material and Method: A total of 296 patients, 166 women and 130 men, participated in the study. A multiple-choice standardized questionnaire containing questions about demographic information and implant treatment was applied to the patients. People who had implants before, had no tooth deficiency and had no knowledge of implant treatment were not included in the study.

Results: $42.2 \%$ of the patients obtained information about implants from doctors or dentists. $74.7 \%$ of the participants preferred to have the implant surgery phase done by a maxillofacial surgeon, and $66.2 \%$ preferred to have prosthesis over the implant done by a prosthesis specialist. When the questionnaire responses of the patients were evaluated with the age variable, it was observed that the awareness level of the individuals under the age of 35 about dental implants was statistically significantly higher $(p<0.05)$.

Conclusion: When the results of this study were evaluated, it was seen that individuals who needed prosthetic dental treatment due to tooth deficiency did not have sufficient knowledge about dental implants. In order to provide patients with more accurate information about dental implants, it is necessary to reach the resources that patients use to obtain information.
\end{abstract}

Keywords: Dental implants, implant-supported dental prosthesis, knowledge, awareness, patients
Öz

Amaç: Diş implant tedavisi günümüzde diş kayıplarının giderilmesinde altın standart olarak kabul edilmektedir. Bu çalışmada Tokat Gaziosmanpaşa Üniversitesi Diş Hekimliği Fakültesi Protetik Diş Tedavisi kliniğine sevk edilen hastaların dental implant tedavileri hakkında bilgi düzeylerinin değerlendirilmesi amaçlanmıştır.

Gereç ve Yöntem: Çalışmaya 166'sı kadın, 130'u erkek olmak üzere toplam 296 hasta katıldı. Hastalara demografik bilgileri hakkında ve implant tedavisi hakkında soruları içeren çoktan seçmeli standardize anket uygulandı. Daha önce implant yaptırmış, diş eksikliği olmayan ve implant tedavisi hakkında hiçbir bilgisi olmayan kişiler çalışmaya dahil edilmedi.

Bulgular: Hastaların \%42,2'si implantlar hakkındaki bilgileri doktor veya diş hekimlerinden edinmişlerdir. Katılımcıların \%74,7'si implant cerrahi aşamasını çene cerrahına yaptırmayı, \%66,2'si ise implant üstü protezleri protez uzmanına yaptırmayı tercih etmiş̧ir. Hastaların anket cevapları yaş değişkeni ile değerlendirildiğinde, 35 yaş altı bireylerin diş implantları konusunda farkındalık düzeylerinin istatistiksel olarak anlamlı derecede daha yüksek olduğu görülmüştür $(p<0,05)$.

Sonuç: Bu çalışmanın sonuçları değerlendirildiğinde, diş eksikliği nedeniyle protetik diş tedavisine ihtiyaç duyan bireylerin diş implantları hakkında yeterli bilgiye sahip olmadıkları görülmüştür. Hastalara diş implantları hakkında daha doğru bilgi verebilmek için hastaların bilgi almak için kullandıkları kaynaklara ulaşıması gerekmektedir.

Anahtar Kelimeler: Diş implantları, implant destekli diş protezi, bilgi, farkındalık, hastalar

Corresponding (illetişim): Kaan Yerliyurt, Tokat Gaziosmanpaşa University Faculty of Dentistry Department of Prosthodontics, Tokat, Turkey E-mail (E-posta): kaanyerliyurt@hotmail.com

Received (Geliş Tarihi): 24.09.2021Ａccepted (Kabul Tarihi): 02.11 .2021 


\section{INTRODUCTION}

Tooth losses occur due to many reasons such as dental caries, traumas, genetic disorders. The loss of natural teeth has been a health problem associated with functional, cosmetic and psychological diseases since ancient times. ${ }^{[1]}$

Various attempts have been made to complete missing teeth with artificial teeth (prostheses) that mimic the function and appearance of natural teeth. ${ }^{[2]}$ There are several alternative prosthetic options for replacing missing teeth. Among these options, the patient's choice of prosthesis type; it was stated that it depends on the education level, economic level, cultural background and age factors of the patients. ${ }^{[3]}$ Dental implant treatment; it has taken its place in the literature as a treatment method that is mostly welcomed by patients and the results are better than other prosthetic methods. ${ }^{[4-8]}$

In over implant prostheses; thanks to the adequate retention and stability of the prosthesis, functional prostheses can be made and thus the quality of life of the patient can be improved. ${ }^{[9]}$ In short, dental implant treatment is accepted as the gold standard today for the elimination of tooth losses. ${ }^{[2]}$

With the advances in dental implant treatment in recent years, this treatment, which has been applied in many indications, helps patients suffering from tooth deficiency and dentists who treat these problems. Among these indications, there are many applications in prosthodontics such as single dental implants applied in single tooth deficiencies, all-on-four implant systems used in total tooth deficiencies ${ }^{[10]}$, implant supported overdenture prosthesis ${ }^{[11]}$, zygoma implants. ${ }^{[12]}$

In different studies conducted in various countries, the awareness and knowledge levels of the patients about dental implant treatments were evaluated. ${ }^{[4,13-23]}$ When we examine the literature made in Turkey in the Tokat province, there is no such a study.

The purpose of the study is to evaluate the knowledge and awareness levels of patients who are referred to the Department of Prosthetic Dentistry, Tokat Gaziosmanpaşa University Faculty of Dentistry, about dental implant treatment.

\section{MATERIAL AND METHOD}

Ethics committee approval was obtained from Tokat Gaziosmanpaşa University Faculty of Medicine Clinical Research Ethics Committee with project number 18-KAEK200 for our study. Our work; it has been made in accordance with the principles of the World Medical Association (WMA) Declaration of Helsinki; informed consent forms were obtained from all patients included in the study.

A standardized questionnaire was conducted to evaluate the knowledge level of patients about the implant. The survey includes information on dental implants as well as demographics. The questionnaire was administered by the researcher to the patients in the form of questions and answers. The survey was conducted by the same researcher to all participants. 296 patients aged $18-75$ years participated in this study. Individuals who had implants before, if there is no tooth loss and had no knowledge about implant treatment were not included in the study.

\section{Statistical Analysis}

Descriptive analyzes were made to give information about the general characteristics of the study groups. IBM SPSS Statistics 25 (IBM Corp., Somers, NY) software was used in statistical analysis. The data of continuous variables are as mean \pm standard deviation. Data on categorical variables are given as $n$ (\%). When comparing the means of quantitative variables between groups, the significance test of the difference between the two means and one-way analysis of variance are used. Cross tables and chi-square tests are used to evaluate whether there is a relationship between qualitative variables.

If $\mathrm{p}<0.05$ was considered statistically significant.

\section{RESULTS}

A total of 296 patients (mean age 45.24 15.59 ) participated in the study, with 166 women (mean age 43.25 14.85 ), 130 men (mean age $47.78 \pm 16.2$ years). The demographic characteristics of the patients are summarized in Table 1.

\begin{tabular}{|c|c|c|}
\hline & $\mathbf{n}$ & $\%$ \\
\hline \multicolumn{3}{|l|}{ Age } \\
\hline $18-25$ & 42 & 14.2 \\
\hline $26-35$ & 55 & 18.6 \\
\hline $36-45$ & 50 & 16.9 \\
\hline $46-55$ & 61 & 20.6 \\
\hline $56-65$ & 61 & 20.6 \\
\hline 66 and over & 27 & 9.1 \\
\hline \multicolumn{3}{|l|}{ Gender } \\
\hline Woman & 166 & 56.1 \\
\hline Man & 130 & 43.9 \\
\hline \multicolumn{3}{|l|}{ Education level } \\
\hline Didn't go to school & 4 & 1.4 \\
\hline Primary school & 113 & 38.2 \\
\hline Middle school & 30 & 10.1 \\
\hline High school & 51 & 17.2 \\
\hline University & 87 & 29.4 \\
\hline Postgraduate & 11 & 3.7 \\
\hline \multicolumn{3}{|c|}{ Income level (in Turkish Liras) } \\
\hline $0-2000$ & 171 & 57.8 \\
\hline $2001-4000$ & 86 & 29.1 \\
\hline $4001-8000$ & 30 & 10.1 \\
\hline 8001 and over & 9 & 3 \\
\hline
\end{tabular}

Participants in the study stated that they obtained their knowledge about dental implants mostly from doctors and dentists (125 people) and secondly from their friends (90 people). The rate of individuals who thought that dental 
implants could be applied in any indication was $73.6 \%$. Regarding the applicability of dental implant treatment to which age groups, $38.5 \%$ of the individuals think that it can be applied in patients over 18 years old, and $46.3 \%$ in patients between the ages of $30-65.57 .1 \%$ of individuals think that dental implants can remain in the mouth for a lifetime. When the preferences of the patients in the question "Which group of dentists or physicians do you have the dental implant placement procedure done?" It is seen that 221 people prefer the "Oral and Maxillofacial Surgeon" group. When the dentist preferences of the individuals in our study at the stage of making prosthetics on implants were examined, the "Prosthodontist" group was among the preference or preferences of 196 patients. Dental implant information of the individuals participating in the study is shown in Table 2.

In the chi-square analysis in which the questionnaire answers were evaluated with the age variable, it was observed that the awareness level of the individuals under the age of 35 about dental implants was statistically higher $(p<0.05)$.

\section{DISCUSSION}

With the definition and development of the concept of osseointegration in dentistry, dental implants have begun to be used with great acceleration in the treatment of missing teeth. ${ }^{[24]}$ The popularity of this treatment, which gives more satisfactory results compared to traditional prostheses, is increasing day by day. With this increasing popularity, patients seek information about dental implants and obtain information from various sources. Although this information is not always correct, it also causes the patient's biased approach to dental implant treatment. Having the patient's knowledge about the procedure to be performed reduces the anxiety that will occur before and after the treatment. When the relevant literature is examined, there are not many studies about the knowledge and awareness of patients about dental implants. In this study conducted in the city of Tokat, the awareness, level of knowledge and preferences of individuals with tooth deficiency about implant treatments were evaluated.

In our study, when the preferences of the patients at the stage of placing dental implants in the bone were examined, among the preference or preferences of $74.7 \%$ of the patients were oral and maxillofacial surgeons. In the preferences of the physician who will make the upper structure of the dental implant; prostodontist was among the preference or preferences of $66.2 \%$ of the patients. In the study conducted by Güngör and Dikeç ${ }^{[13]}$, who evaluated the awareness of patients in the Eastern Anatolia Region about dental implant treatments, the participants were asked "where they prefer to have the implant done" and $60.5 \%$ of the participants chose to have it done by a specialist dentist. The findings of both studies are similar in terms of the physician preference of the participants in implant treatment.

In the study conducted by Siddique et al. ${ }^{[15]}$ in India, the rate of patients who thought that dental implants were expensive
Table 2. Responses of the individuals to the questionnaire about dental implants

\section{n}

\section{$\%$}

\begin{tabular}{lcc}
\hline Where did you get the most information about dental implants? \\
Friend & 90 & 30.4 \\
Doctor and dentist & 125 & 42.2 \\
Internet/TV & 67 & 22.6 \\
Newspaper and magazine & 3 & 1 \\
Health employee & 11 & 3.7 \\
Can implant treatment be applied to everyone? & & \\
Yes & 78 & 26.4 \\
No & 218 & 73.6
\end{tabular}

What is your opinion about the age range of implant treatment?

$\begin{array}{lcc}\text { 12-18 years old } & 5 & 1.7 \\ \text { Above } 18 \text { years old } & 114 & 38.5 \\ \text { 30-65 years old } & 137 & 46.3 \\ \text { Over } 50 \text { years old } & 40 & 13.5 \\ \text { implant treatment a life-long treatment? } & & \\ \text { Yes } & 169 & 57.1 \\ \text { No } & 127 & 42.9\end{array}$

*Which is or which ones are related the duration of the implants in the mouth?

Oral hygiene of the patient 45.6

General health status 135 55.4

Preferred implant type

164 31.8

The competence of the physician or physicians in this field whose performing the application

*Which material or materials are dental implants made of ?

Porcelain 75

25.3

Stainless steel

93

31.4

Titanium

83

28

Titanium/Zirconium Alloy

61

20.6

*If you do not want to have a dental implant, which or which ones of the following will cause you to make this decision?

To be expensive

$140 \quad 47.3$

Fear of surgical operation

77

26

Foreign body entering the body

7.1

I think it's harmful to health

21

9.8

It is a long-lasting form of treatment

29

*Which group of dentist/specialist dentist would you prefer to have the dental implant placed in the jawbone?

Oral and Maxillofacial Surgeon $\quad 221$

$\begin{array}{lll}\text { Periodontist } & 32 & 10.8\end{array}$

$\begin{array}{lll}\text { Prosthodontist } & 54 & 18.2\end{array}$

General Dental Practitioner $\quad 10 \quad 3.4$

*Which group of dentists or specialist dentists you prefer for being done the dental implant superstructure?

Oral and Maxillofacial Surgeon $\quad 65 \quad 22$

$\begin{array}{lrl}\text { Periodontist } & 23 & 7.8\end{array}$

$\begin{array}{lll}\text { Prosthodontist } & 196 & 66.2\end{array}$

General Dental Practitioner

$18 \quad 6.1$

More than one option can be selected. 
was $60.4 \%$. In this study, $11.6 \%$ of the patients think that the obstacle in front of dental implant treatment is that the surgical procedure is a difficult procedure. In another study investigating the awareness of patients about implant treatments; $35.2 \%$ of the patients stated that their costs were high when asked about the factors that prevent implant treatment. ${ }^{[19]}$ Murkute et al. ${ }^{[25]}$ in their study; stated that cost is the main barrier to choosing implant treatment for patients (49\%). In our study, $47.3 \%$ of the participants stated that implant treatment is an expensive treatment, and $26 \%$ stated that they feared surgical procedure. Looking at the results of our study, it is seen that they are similar to the results of other researchers.

In our study, $57.1 \%$ of the participants think that the usage period of the dental implant is lifetime. In the study of Menziletoğlu et al. ${ }^{[26]}, 69.2 \%$ of the participants stated that the implant treatment was long-term. In another study, $55.1 \%$ of individuals stated that the implants remained in the mouth for more than 20 years or for a lifetime. ${ }^{[27]}$ The results of the authors support our study.

Patients have obtained their knowledge about dental implants from various sources. In our study, $42.2 \%$ of the individuals stated that they had information about dental implants from doctors/dentists, 30.4\% from their friends, $22.6 \%$ from the internet/TV and $4.7 \%$ from other sources. Mukatash et al. ${ }^{[8]}$, Erzurumlu et al. ${ }^{[17]}$, Pommer et al.[28], Kohli et al. ${ }^{[29]}$, Özcan Küçük et al. ${ }^{[30]}$ reported that participants mostly learned the information about dental implants from their dentists. These results show similarities with our study. Differently; Peker Ozturk et al. ${ }^{[31]} 57.7 \%$ of individuals stated that they obtained information from media organs (TV, radio, internet, magazine, newspaper, etc.).

In the group consisting of patients who applied to the clinic for dental implants in the study of Memiş ${ }^{[20]}$ in 2020; 54.1\% of the participants said "I don't know", 22.9\% said "titanium", and $12.8 \%$ said "stainless steel", to the question about which material dental implants are made of. In the study conducted by Deeb et al. ${ }^{[18]}, 70 \%$ of the participants in the patient group who were thinking of having an implant for the same question chose "titanium". When the answers given by the patients to the question about the materials used for dental implants were examined in our inpatient study; it is seen that in total, $48.6 \%$ of the choice is titanium and/or titanium-zirconium alloy. According to these results, individuals participating in our study; it can be interpreted that they have more knowledge about the basic materials used in the production of dental implants at a lower rate than the study group made by Memiş ${ }^{[20]}$ and less than the working group of Deeb et al. ${ }^{[18]}$

\section{CONCLUSIONS}

When the results of the present study were evaluated, it was seen that individuals suffering from tooth deficiency did not have sufficient knowledge about dental implants. In order to provide more accurate information about dental implants to patients, the resources that patients use to obtain information should be accessed. As a professional, dentists have a great responsibility in this regard. To ensure that patients have more and more accurate information about dental implant treatments; organizing patient education programs and establishing counseling centers about the indications, advantages and possible complications of dental implants will be beneficial.

\section{ETHICAL DECLARATIONS}

Ethics Committee Approval: Ethics committee approval with project number 18-KAEK-200 was obtained from Tokat Gaziosmanpaşa University Faculty of Medicine Clinical Research Ethics Committee on 2018-09-25.

Informed Consent: All patients signed the free and informed consent form.

Referee Evaluation Process: Externally peer-reviewed.

Conflict of Interest Statement: The authors have no conflicts of interest to declare.

Financial Disclosure: The authors declared that this study has received no financial support.

Author Contributions: All of the authors declare that they have all participated in the design, execution, and analysis of the paper, and that they have approved the final version.

\section{REFERENCES}

1. Mgbeokwere U, Okoye L, Ekwueme O. A survey of the knowledge of dental implants as a choice in treatment of edentulous jaws among health workers in government dental clinics in Enugu. Ann Med Health Sci Res 2011;1(1):91-5.

2. Sivaraman K, Chopra A, Narayan Al, Balakrishnan D. Is zirconia a viable alternative to titanium for oral implant? A critical review. J Prosthodont Res 2018;62(2):121-33.

3. Jayasinghe RM, Perera J, Jayasinghe V, et al. Awareness, attitudes, need and demand on replacement of missing teeth among a group of partially dentate patients attending a university dental hospital. BMC Res Notes 2017; 10:334.

4. Al-Johany S, Al Zoman HA, Al Juhaini M, Al Refeai M. Dental patients' awareness and knowledge in using dental implants as an option in replacing missing teeth: A survey in Riyadh, Saudi Arabia. Saudi Dent J 2010;22(4):183-8.

5. Wang Y, Bäumer D, Ozga AK, Körner G, Bäumer A. Patient satisfaction and oral health-related quality of life 10 years after implant placement. BMC Oral Health 2021;21:30.

6. Awadalkreem F, Khalifa N, Satti A, Suleiman AM. The influence of immediately loaded basal implant treatment on patient satisfaction. Int J Dent. 2020;2020:6590202.

7. Bakker MH, Vissink A, Meijer HJ, Raghoebar GM, Visser A. Mandibular implant-supported overdentures in (frail) elderly: A prospective study with 20-year follow-up. Clin Implant Dent Relat Res 2019;21 (4):586-92.

8. Mukatash GN, Al-Rousan M, Al-Sakarna B. Needs and demands of prosthetic treatment among two groups of individuals. Indian J Dent Res 2010;21(4):564-7.

9. Gbadebo OS, Lawal FB, Sulaiman AO, Ajayi DM. Dental implant as an option for tooth replacement: The awareness of patients at a tertiary hospital in a developing country. Contemp Clin Dent 2014;5(3):302-6.

10. Durkan R, Oyar P, Deste G. Maxillary and mandibular all-on-four implant designs: A review. Niger J Clin Pract 2019;22(8):1033-40. 
11. Matthys C, De Vijlder W, Besseler J, Glibert M, De Bruyn H. Costeffectiveness analysis of two attachment systems for mandibular overdenture. Clin Oral Implants Res 2020;31(7):615-24.

12. Trevisiol L, Procacci P, D'Agostino A, Ferrari F, De Santis D, Nocini PF. Rehabilitation of a complex midfacial defect by means of a zygomaimplant-supported prosthesis and nasal epithesis: a novel technique. Int $J$ Implant Dent 2016;2(1):7.

13. Güngör H, Dikeç E. Doğu Anadolu Bölgesinde implant tedavisi hakkında hastaların bilgi düzeyinin araştırılması. Atatürk Üniv Diş Hek Fak Derg 2015;25(2):205-12.

14. Özçakır Tomruk C, Özkurt-Kayahan Z, Sençift K. Patients' knowledge and awareness of dental implants in a Turkish subpopulation. J Adv Prosthodont 2014;6(2):133-7.

15. Siddique EA, Bhat PR, Kulkarni SS, Trasad VA, Thakur SL. Public awareness, knowledge, attitude and acceptance of dental implants as a treatment modality among patients visiting SDM College of Dental Sciences and Hospital, Dharwad. J Indian Soc Periodontol 2019;23(1):58-63.

16. Chowdhary R, Mankani N, Chandraker NK. Awareness of dental implants as a treatment choice in urban Indian populations. Int J Oral Maxillofac Implants 2010;25(2):305-8.

17. Ünal Erzurumlu Z, Kara ZS. Diş Hekimliği Fakültesi'ne başvuran hastaların dental implant farkındalıklarının değerlendirilmesi. Selcuk Dent J 2018;5:212-7.

18. Deeb G, Wheeler B, Jones M, Carrico C, Laskin D, Deeb JG. Public and patient knowledge about dental implants. Oral Maxillofac Surg 2017;75:1387-91.

19. Saha A, Dutta S, Vijaya V, Rajnikant N. Awareness among patients regarding implants as a treatment option for replacement of missing teeth in Chattisgarh. J Int Oral Health 2013;5(5):48-52.

20. Memiş S. Türkiye'nin Batı Karadeniz Bölgesinde dental implantlar hakkında hastaların bilgi ve farkındalığı. Turkiye Klinikleri J Dental Sci 2020;26(3):323-30.

21. Kranjcic J, Mikus A, Mehulic K, Vojvodic D. Knowledge and awareness of dental implants among elderly people in Croatia. J Prosthodont 2015;24:37-42.

22. Tanvir M, Izhar F, Yazdannie N, Kamal MM. General awareness and acceptance of dental implants in patients attending a tertiary care hospital. J Rehman Coll Dent 2021;2(1):2-6.

23. Salim NA, Meyad FH, Al-Abdallah MM, Motasum Abu-Awwad M, Satterthwaite JD. Knowledge and awareness of dental implants among Syrian refugees: a cross sectional study in Zaatari camp. BMC Oral Health 2021;21:442.

24. Henry PJ. Oral implant restoration for enhanced oral function. Clin Exp Pharmacol Physiol 2005;32(1-2):123-7.

25. Murkute S, Beldar A, Thakkar P, Thamke M. A cross-sectional epidemiological study to evaluate the awareness of patients and private dental practitioners regarding dental implant therapy in Nashik. IOSR J Dent Med Sci 2017;16(1):22-6.

26. Menziletoğlu D, Kılınç A, Işık BK, Akın C. Assesment of dental implant awareness and knowledge levels of patients. Yeditepe J Dent. 2020;16(3):209-12.

27. Al-Rafee M, Adam HI, Alharbi TS, Almojel AA. Public awareness and knowledge of dental implants in Riyadh, Saudi Arabia. Saudi J Oral Sci 2018;5(2):110-4.

28. Pommer B, Zechner W, Watzak G, Ulm C, Watzek G, Tepper G. Progress and trends in patients' mindset on dental implants. I: level of information, sources of information and need for patient information. Clin Oral Implants Res 2011;22(2):223-9.

29. Kohli S, Bhatia S, Kaur A, Rathakrishnan T. Patients awareness and attitude towards dental implants. Indian J Dent 2015;6:167-71.

30. Özcan Küçük A, Keskinrüzgar A, Şimşek HO. Hastaların dental implantlara bakış açııının değerlendirilmesi. Mersin Univ Saglık Bilim Derg 2021;14(2):232-41.

31. Peker Öztürk H, Özgedik HS, Avsever H, et al. Awareness, attitude, and knowledge of dental patients regarding dental implant treatment in an urban population: a cross-sectional study in Turkey. J Stoma 2019;72(3):112-7. 